\title{
Socio-thermal Analysis of Pawon Gebulen Kraton Yogyakarta
}

\section{Nurina Vidya Ayuningtyas ${ }^{1}$, Desy Ayu Krisna Murti ${ }^{1}$, Istiana Adianti ${ }^{1}$} Department Architecture, Universitas Widya Mataram, Dalem
Mangkubumen KT III/237 Kraton Yogyakarta

\author{
Article History \\ Received : 28 August 2021 \\ Accepted : 20 September 2021 \\ Published : 30 October 2021
}

\begin{abstract}
Architecture is a part of spatial planning closely related to the culture that surrounds the community. One of the fascinating things is digging up information about the architecture of the Yogyakarta Palace. There are many parts of the architectural layout of the palace that are very interesting to explore; one of them is Pawon. The research method used is a combination of measurements or direct observations in the field with software simulations. The results of this study can conclude that the Pawon Gebulen Kraton Yogyakarta building has not fulfilled the thermal comfort standard. The determining factor of thermal comfort discovered in this research is related to the temperature and heat due to the heat transfer of natural lighting into the building. Despite the discomfort, the royal courtiers or Abdi Dalem still voluntarily work in that place. It is because of the high social spirit of the community and the strong will in serving the Sultan.
\end{abstract}

Keywords: kitchen; kraton; light; pawon; temperature; thermal

\section{Introduction}

It is common knowledge that traditional architectures throughout Indonesia have elements of cultural identity. The definition of conventional architecture in question is an architecture whose birth is motivated by local norms and customs as well as local conditions (Handayani, 2019). The fact is that the move towards traditional architecture requires the ability and understanding of people, nature, and the environment as a whole (Satriana, 2009). Furthermore, we do not only move around the architectural object but also move through it as well. It means that architecture gives us an exceptional opportunity to experience symmetry and see through it (Adityaningrum, 2020). The architecture consists of two distinct components, namely solid and void. The elements that make up the components in architecture are the solid ones, and thus it is possible that, with these components, ordinary people can feel the architectural experience

Correspondence: Nurina Vidya Ayuningtyas Department Architecture, Universitas Widya Mataram, Dalem Mangkubumen KT III/237 Kraton Yogyakarta E-mail: nurina.vidya@gmail.com
(Widayatsari, 2002). Naturally, in the composition of intact elements, various types of symmetrical relationships will be found (Zain, 2012).

Architecture is a field of science that is closely related to culture (Yuniastuti, 2019). All kinds of spatial parts in architecture are very closely related to the culture that surrounds the community. One of the most crucial things is to dig up information about the architecture of the Yogyakarta Palace since there are so many parts of the architectural layout of the palace that are very interesting to be thoroughly explained (Prabasmara,2019). One of the highlights is Pawon.

The kitchen/Pawon is a place to serve or prepare food. In both traditional and modern buildings, almost all kitchens run these activities (Nuryanto, 2010). For the conventional ones, it even shows that the function of the kitchen is not only for preparing or serving food. The kitchen's function is closely related to social and ritual aspects. A traditional kitchen can function as a place for social interaction for the users and prepare the required offerings (Nuryanto, 2010). Pawon is an essential thing 
in a residential house and, in this case, includes the king's residence (Kraton). If we look at the context of the spatial hierarchy in the Kraton, we cannot compare the Pawon with Gedhong or other Bangsal (Ashadi, 2017). However, Pawon is essential since it functions to provide foods, either tangible or intangible.

Pawon/kitchen is one of the architectural concepts that prioritize elements of local tradition and culture. The local culture and traditional components include geography, climate, material, culture, and beliefs. Activities in the Pawon/kitchen are also unique, where many active activities can increase the room temperature significantly. Javanese people commonly gather and socialize in the kitchens. Then, when cooking foods or using stoves are performed by many people simultaneously, it will result in a high occupancy rate within the area. Therefore, in this study, we will examine the concept of thermal comfort in the Pawon/ kitchen building seen from the temperature aspect and other supporting characteristics. In the Kraton, there are several Pawon buildings, but this article will only focus on explaining the Pawon Gebulen building.

\section{Literature Review}

The kitchen plays an essential role in a series of buildings. In traditional buildings in Aceh, the kitchen is an area that is vital to serving food sources to its residents. In traditional Aceh buildings, there is a striking difference compared to other rooms, namely the height of the floor. The elevation of the kitchen area is almost parallel to or is lower than other rooms (Hasbi, 2017).

It is in line with the results of research on traditional Sundanese buildings. Nuryanto (2020) stated that Pawon is not only a cooking area. It covers other dimensions related to customs. The phenomenon of Pawon is full of social functions and traditional rituals and has symbolic-mystical meanings. Sundanese people who deeply honor their ancestral traditions believe that a house has a physical and a metaphysical dimension or something related to supernatural parts. For them, the house has a 'soul' just like humans have a spirit. Hence, every process of building is not arbitrary (Sabdacaraka, 2008).
Based on information from the Wewangunan Rafting System (Kraton.id, accessed on Saturday, September 12, 2020) Pawon in the Yogyakarta Palace include Pawon Wetan, Pawon Kilen, Pawon Patehan, Pawon Prabeyo, Pawon Gondokusuman, and Pawon Garwo is the name of a place that functions as a kitchen at the Yogyakarta Palace (Brongtodiningrat, 1978). The word "Pawon" itself comes from the root word "awu" which means ash. It describes the state of a traditional kitchen filled with ashes from the stove (Rusnandar, 2015). Pawon has an essential meaning and function in food preparation, storage, and other activities (Sukirman, 2011). From time to time, the kitchen is changing according to the needs and needs of the Sultan. The main examination in this research includes the changes in function, layout, circulation pattern, ventilation, and lighting that carry out their roles as a kitchen in the Yogyakarta Palace environment. It extends to which Kraton interprets and treats Pawon to fulfill the need for food, drink, and other spiritual needs (Yuniastuti et al., 2009). It is also part of prayer in daily life in which food offerings can cleanse themselves from disaster and calamity from the beginning until this pandemic period.

The Pawon layout is a fascinating object to review because it is necessary to know more about the design of the area/zone in Pawon (Punto, 2001). Based on this information, several research approaches related to Pawon are proposed, specifically about the thermal condition of the room. Concerning the importance of air conditioning in the room in providing food preparations, there is a change from what used to be a stove and now is so-called a stove. The identification of Pawon spatial layout is a place for cooking and preparing food (Ayuningtyas et al., 2019). In Pawon, all cooking utensils, stoves, firewood, and some cooking ingredients are stored within and ready to use. It is also captivating to examine the spatial pattern of Pawon because it is related to the effectiveness of the users during their activities.

Pawon Gebulen is one of the Pawon that is crucial in every activity in the Kraton. Pawon Gebulen provides Kabuli rice as an offering for a ritual process or affairs in the Kraton.

Thus, the temperature indicator used as the benchmark is inseparable concerning the thermal comfort of a room. The actual 
measurement of the comfort level of humans who inhabit the space is the Operative Temperature value. The Operative Temperature is the average value of the sum of the air temperature and the mean radiant temperature and is the temperature felt directly by human skin (Ayuningtyas, 2019).

Material selection will also considerably affect the thermal condition of the building (Harapan, 2018). One material that plays an essential role concerning temperature is glass material. The selection of glass materials with a low heat transmission value into buildings can be the best choice. As previously explained, the SHGC variation shows the most effective application if viewed from the wide temperature range that can decrease. The SHGC variation is regarded as the most effective material because the use of small type SHGC (type 0.2-0.4) is quite capable of withstanding direct transmission of solar radiation and the spread of solar radiation transmission (Ayuningtyas et al., 2019).

\section{Methodology}

The research method used is a combination of measurements or direct observations in the field with software simulations. Measurements and field monitoring are needed to determine the actual conditions so that they can feel directly empirically (Sary, 2015), and software calculations are carried out to check data in the field. Data collection in the field observations used measuring instruments (meters, lux meters, thermometers, et cetera). Results from direct measurements and software simulation in numbers show the temperature quantity in the already determined area. The unit of that temperature is ${ }^{\circ} \mathrm{C}$.

Field observations or observations are needed to obtain data in documents/data format, both regarding facilities and infrastructure. Observing the object first hand is also to collect data and determine the condition of the selected object, including the site condition, the shape of the site, the environment surrounding it, and others (Febrianto, 2018). In addition, the method also added the interview with several sources related to the Pawon in Kraton Yogyakarta Building.

This study also performs measurements with software simulations such as Ecotect.
Ecotect calculated the total radiation used to determine the amount of radiation exposure in each area of the building envelope. Then, it could determine whether or not the shape and orientation of the building are good enough to minimize the amount of radiation exposure that falls on the surface of the building envelope. Then, simulations with the help of computer software calculated that model (Ayuningtyas et al., 2019). In addition to location and orientation, simulations applied different wall and glass materials for each unit. The simulation displayed a mapping of the intensity of natural light that enters the room (BSN, 2001). Ecotect measurements took place midday at 12 with the Yogyakarta weather file.

Figure 1. Simulation Image

Source: Author, 2020

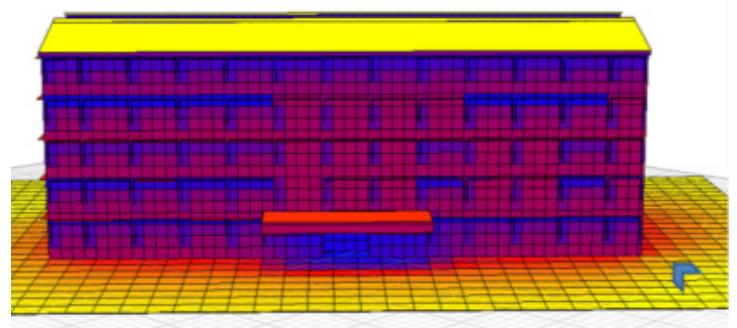

The preparation and analysis of the research involved qualitative and quantitative methods. Qualitative methods are more concerned with interpreting the data found in the field involving descriptive observation and field interviews. Meanwhile, a quantitative analysis is concerned with mathematical calculations based on data gathered on field studies or observations and on-field measurement.

\section{Result and Discussion}

Before doing the simulation, here is an overview of the shape of the building. It displays perspective drawings, floor plans, and sections. 
Figure 2. Floor Plan

Source: Author, 2021

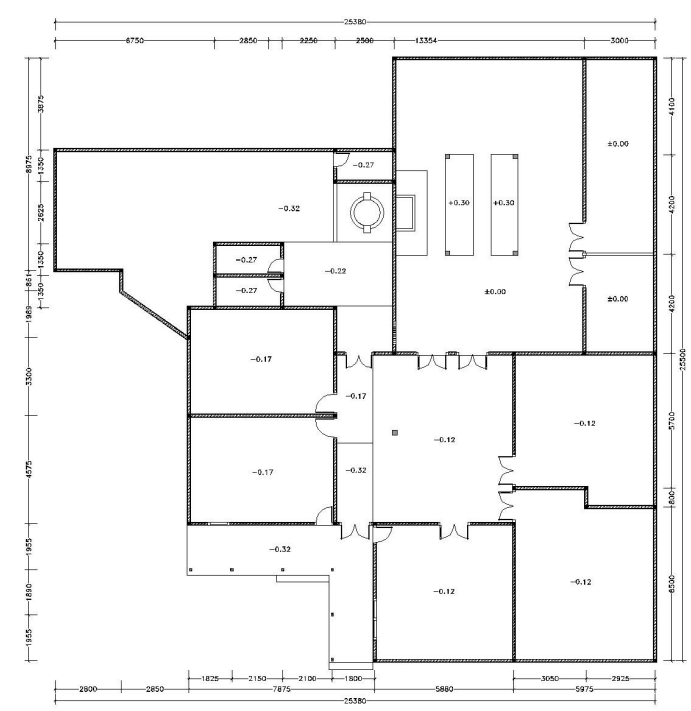

Figure 3. Perspective Source: Author, 2021

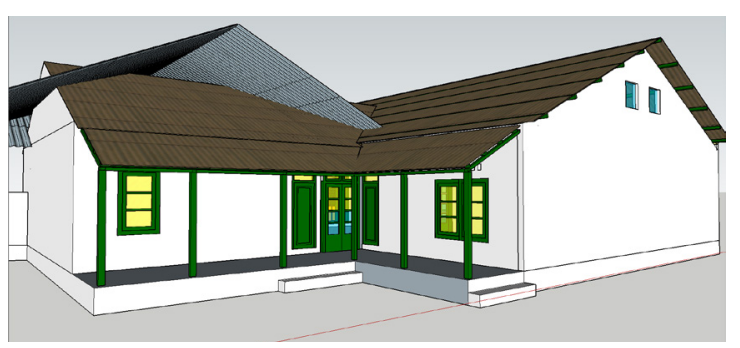

Figure 4. Section Image Source: Author, 2021

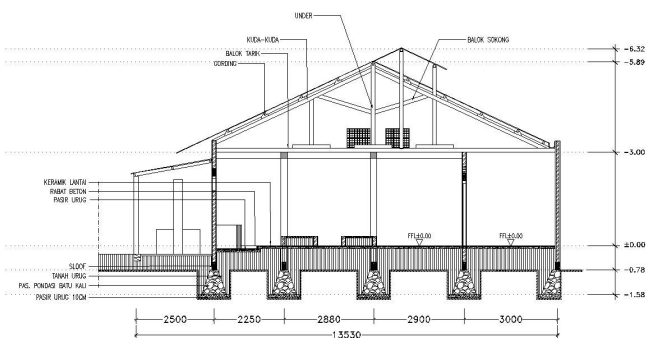

Several analyses using software methods and direct calculations have been carried out. The following is an illustration of the results of simulation calculations using Ecotect software.
Figure 5. North Side Ecotect Simulation Results Source: Author, 2021

gercrarreasurs

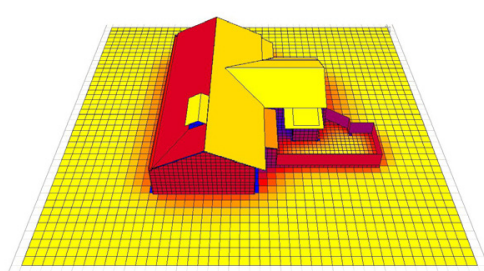

Figure 6. East Side Ecotect Simulation Results Source: Author, 2021

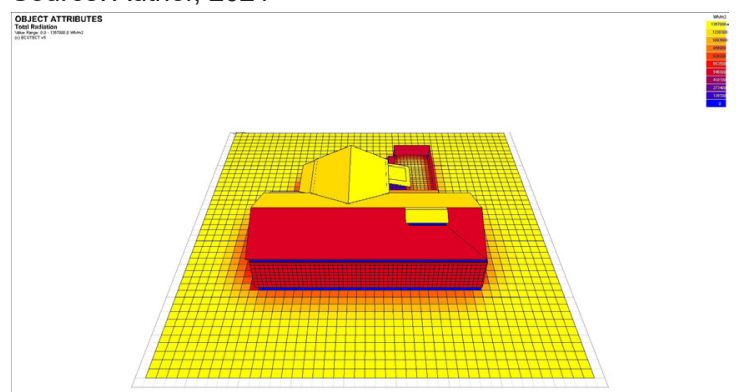

Figure 7. South Side Ecotect Simulation Results Source: Author, 2021

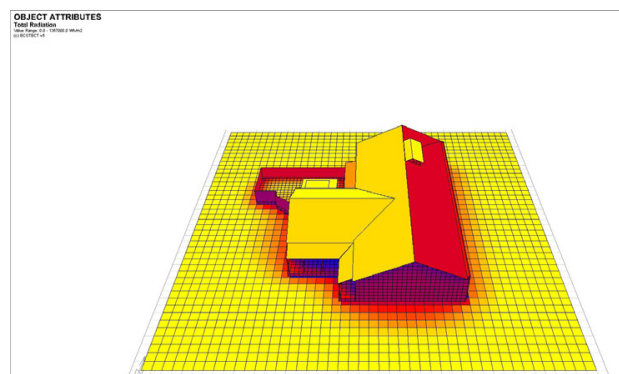

Figure 8. West Side Ecotect Simulation Results Source: Author, 2021 gakcramenanus

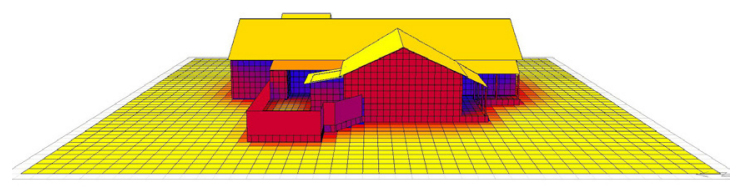

Looking at the simulation results of the Ecotect software, it showed that almost all parts of the skin of the Pawon building received a reasonably high thermal heat, seen from the color produced based on the results of the Ecotect simulation. The colors showed average colors of yellow and red, indicating the high heat or temperature has hit this building. 
Journal of Architectural Research and Design Studies Volume 5 Number 2 (October 2021)

75

Of the four cardinal directions, the west is the one that gets high exposure to the sun. It is due to the high intensity of the sun coming from the west. The lowest heat intensity or temperature is from the south because the direction of the sun's circulation in the south is the lowest.

After seeing the results of the Ecotect simulation, the researchers did further research by taking the data straight to the field using the help of measuring instruments such as thermometer and lux meter. The thermometer measured the room temperature while the lux meter calculated the intensity of sunlight entering the room.

Figure 9. Temperature measurement zone point Source: Author, 2021

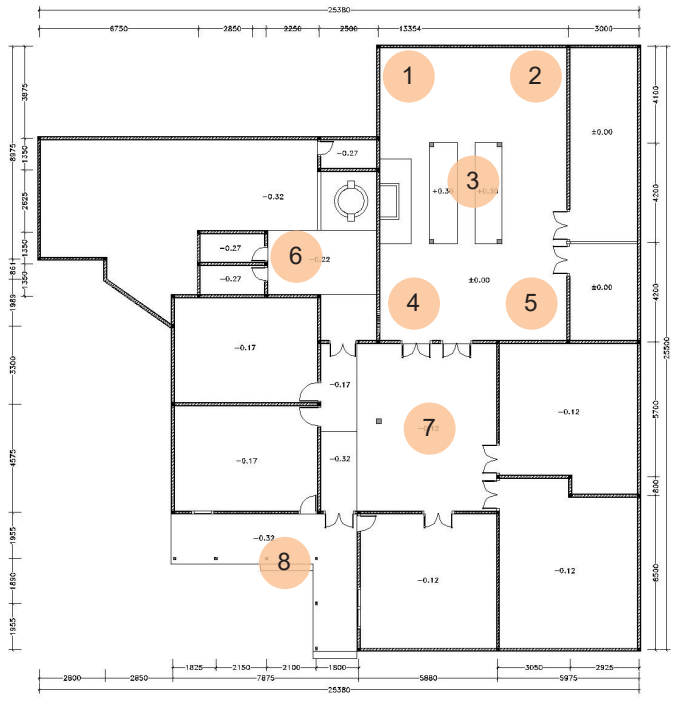

Measurement of temperature, one of the indicators of thermal comfort, was performed in two ways; using energy plus software and direct measurements.

Table 1. Temperature Measurement Results with Simulation

\begin{tabular}{c|cc}
\hline No & Room Area & Temperature \\
\hline 1 & Zone 1 & $30.1{ }^{\circ} \mathrm{C}$ \\
2 & Zone 2 & $29.5{ }^{\circ} \mathrm{C}$ \\
3 & Zone 3 & $32.5{ }^{\circ} \mathrm{C}$ \\
4 & Zone 4 & $33.1{ }^{\circ} \mathrm{C}$ \\
5 & Zone 5 & $30.2{ }^{\circ} \mathrm{C}$ \\
6 & Zone 6 & $28.2{ }^{\circ} \mathrm{C}$ \\
7 & Zone 7 & $28.9{ }^{\circ} \mathrm{C}$ \\
8 & Zone 8 & $31.1{ }^{\circ} \mathrm{C}$ \\
\hline
\end{tabular}

Table 2. Temperature Measurement Results with Direct Measurement

\begin{tabular}{c|cc}
\hline No & Room Area & Temperature \\
\hline 1 & Zone 1 & $30.3{ }^{\circ} \mathrm{C}$ \\
2 & Zone 2 & $29.6{ }^{\circ} \mathrm{C}$ \\
3 & Zone 3 & $32.8{ }^{\circ} \mathrm{C}$ \\
4 & Zone 4 & $33 .{ }^{\circ} \mathrm{C}$ \\
5 & Zone 5 & $30.6{ }^{\circ} \mathrm{C}$ \\
6 & Zone 6 & $28.6{ }^{\circ} \mathrm{C}$ \\
7 & Zone 7 & $29.2{ }^{\circ} \mathrm{C}$ \\
8 & Zone 8 & $31.3{ }^{\circ} \mathrm{C}$ \\
\hline
\end{tabular}

Source: Author, 2021

The temperatures were not much mismatched, seen from the results of the software analysis and actual measurement. In the calculation, the selection of zone points was based on assumptions. Thus, it can represent a picture of the room temperature at some of these points. On the other hand, based on direct measurements, the lowest temperature happened in zone 6, where the area is an outdoor space and is close to several plants and uses shading with a reasonably wide size.

Figure 10. Lowest temperature area image Source: Author, 2021

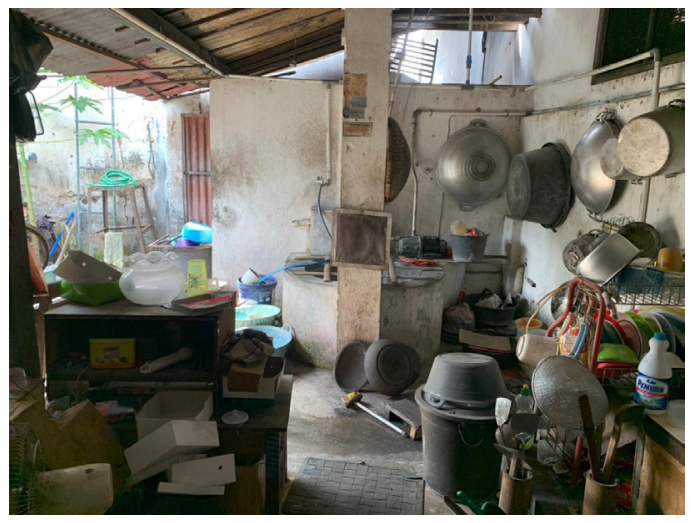

The picture above shows the zone 6 area that is a relatively dim room condition where the temperature in the room is considerably low compared to other zones.

Meanwhile, the highest temperature happened in zone 3 and 4 . Zone 3 has a condition where the upper part has direct access to skylights so that the sun heat can enter this area. Zone 4 has a relatively high temperature because there is a furnace that transfers heat to that area.

Source : Author, 2021 
Figure 11. Picture of the highest temperature area Source: Author, 2021

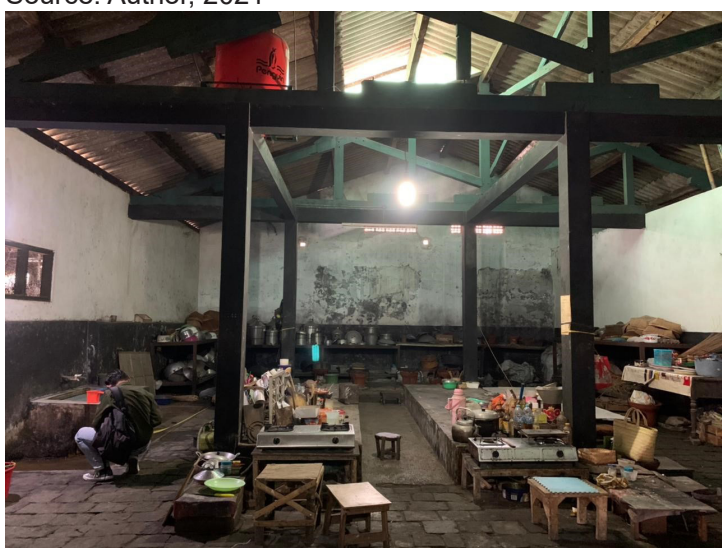

Figure 12. Picture of the highest temperature area Source: Author, 2021

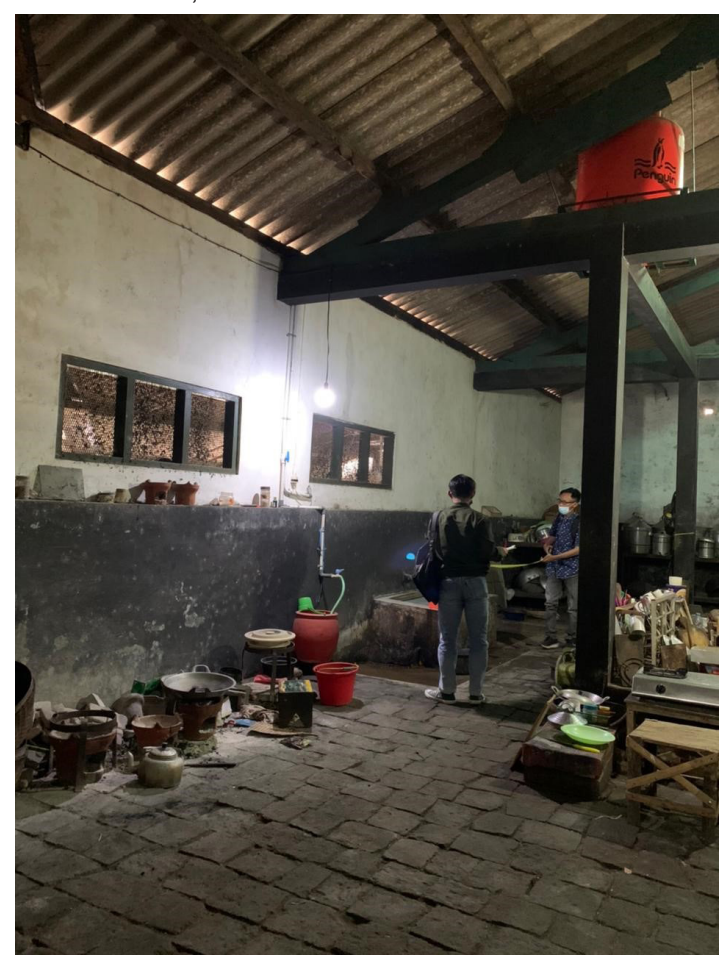

Based on the results of software simulation and direct measurement using a room thermometer, several things influenced the temperature conditions of Pawon Gebulen. Firstly, skylights can cause the sunlight to penetrate the building through the roof, and secondly, the furniture contributes to the heat inside the room. One of the pieces of furniture that affect room temperature is a stove for cooking. This furnace stays in place and does not move, so the area surrounding it is greatly affected by its temperature when being turned on.
Figure 13. Picture of furniture layout Source: Author, 2021

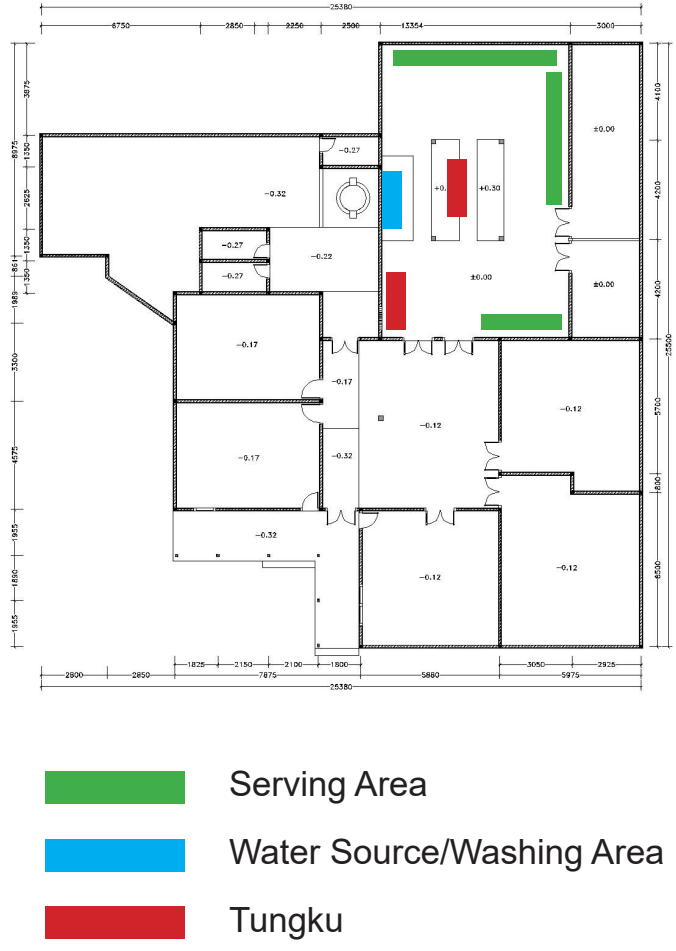

The findings conclude that the building room temperature was still above the standard. The minimum openings of the building made the air circulation flow very minimal. Other than that, the furniture in this building contributed to the heat in the area.

Talking about the furniture layout and looking at the results of the software simulation and direct measurements, the highest temperature in that space was where the furnace stayed. The tool contributed to a high heat transfer potential to the surroundings.

Another factor that affects thermal comfort is the light factor in the room. The greater the light that enters the room, the higher the heat will be. Measurement of the amount of light intensity used a lux meter with a unit of measure lux. 
Figure 14. Point Zone measurement of light intensity Source: Author, 2021

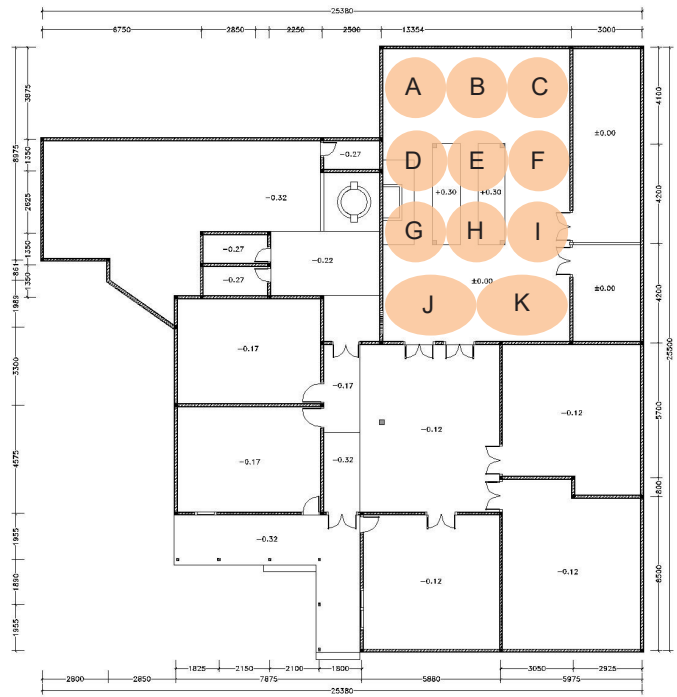

Table 3. Light intensity measurement results

\begin{tabular}{c|cc}
\hline No & Room Area & Light Intensity \\
\hline 1 & Zone A & $101 \mathrm{lux}$ \\
2 & Zone B & $112 \mathrm{lux}$ \\
3 & Zone C & $93 \mathrm{lux}$ \\
4 & Zone D & $278 \mathrm{lux}$ \\
5 & Zone E & $260 \mathrm{lux}$ \\
6 & Zone F & $123 \mathrm{lux}$ \\
7 & Zone G & $131 \mathrm{lux}$ \\
8 & Zone H & $31.3 \mathrm{lux}$ \\
9 & Zone 1 & $127 \mathrm{lux}$ \\
10 & Zone J & $123 \mathrm{lux}$ \\
11 & Zone k & $135 \mathrm{lux}$ \\
\hline
\end{tabular}

Source: Author, 2021

The measurements of light intensity levels found that the highest light intensity happened in $\mathrm{E}$ and $\mathrm{H}$ areas since these two areas are influenced by the presence of skylights on the roof, allowing sunlight to enter during the day. The lowest intensity happened in area C, located at the far left, and there are no openings or access to natural light entering this area.

Also, based on the result of temperature and light intensity measurements, there was a straight comparison between the amounts of light intensity that can affect the temperature scale. The higher the light intensity, the higher the temperature in the area will be. On the contrary, the lower the light intensity, the lower the temperature in the place will be. Also, zone 3 produced high temperatures due to the influence of $E$ and $H$ areas that have skylights above them.

Figure 15. Skylight overview Source: Author, 2021

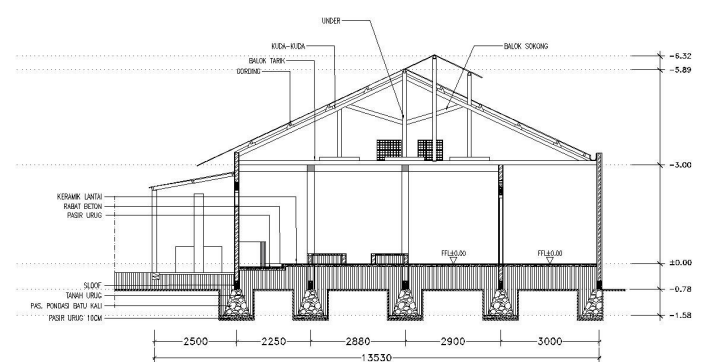

Figure 16. Skylight photo

Source: Author, 2021

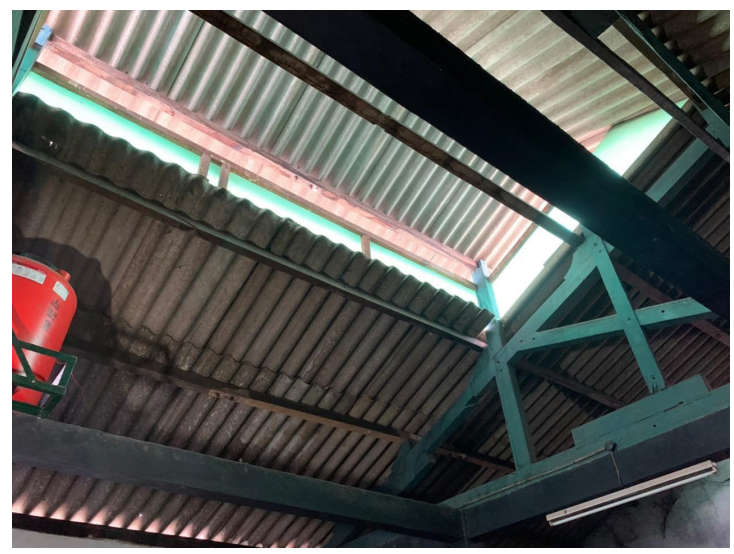

Furthermore, based on simulation and direct measurements, the results were disproportionate to the well-received practice in the field. In an interview, one of the royal courtiers or Abdi Dalem of the Pawon Gebulen expressed his pleasure in working in that place despite its hot temperature.

This building uses brick materials on the walls and asbestos on the roof. The natural light source comes from transparent glass with an SHGC value of 0.8 . The use of brick materials is sufficient to retain heat entering the building. However, the asbestos materials on the roof lead to high heat inside the building. They can transmit a relatively high heat from the outside into the building that advances the temperature of that place.

In this case, this research measured the temperature of Pawon Gebulen and the heat transmitted through natural light into the building. Also, this study did not calculate the 
airflow rate since this will be the focus of further research. Further studies also need to identify why the royal courtiers or Abdi Dalem of Pawon Gebulen volunteer and feel no problems working in such a heated room.

\section{Conclusion}

Based on the software simulations and field measurements, this study concludes that the Pawon Gebulen Kraton Yogyakarta has not fulfilled the thermal comfort standard. Data of the temperature measurements and the results showed a relatively high temperature, above the thermal comfort standard of $25^{\circ} \mathrm{C}$. The average temperature in this room was around $30^{\circ} \mathrm{C}$. Meanwhile, the light intensity showed higher results than the existing standard for a kitchen room of 200 lux. The average light intensity in this room was in the range of 240 lux. This result showed that the higher the light intensity, the higher the temperature in the room will be. Yet, further studies should examine why the royal courtiers feel comfortable working in a high-temperature room. The acceptable reason behind the royal courtiers' willingness comes from their high social spirit and their strong will in serving the Sultan. For this reason, whatever the conditions in which they are active, the courtiers whose jobs are in the kitchen will remain voluntary and happy to work in that place despite the discomfort they might endure. Their strong will and soul of service also spring from their obedience to their leader. Ngarsa Dalem Sri Sultan HB X.

\section{References}

Adityaningrum, D., Pitana, T. S., \& Setyaningsih, W. (2020). Arsitektur Jawa pada Wujud Bentuk dan Ruang Masjid Agung Surakarta. Sinektika: Jurnal Arsitektur, 17(1), 54-60. https://doi.org/10.23917/ sinektika.v17i1.10864

Ashadi (2017). Keraton Jawa. Jakarta: Arsitektur UMJ Press. https://www. researchgate.net/publication/319442076_ Keraton Jawa

Ayuningtyas, N. V., Adianti, I., \& Suryabrata, J. A.. (2019). Study Of "Rusun" Typology Based On Thermal Comfort Analysis Using Software Simulation Method In Rusunawa Type-30. Journal of Architecture and Engineering, 18(2),101-102. doi 10.12962/ j2355262x.v18i2.a5738
Ayuningtyas, N. V., Iskandar, N. Suryabrata, J. A. (2019). Study of the Characteristics of Glass Materials that Influence the Level of Thermal Comfort and Building Energy Consumption with Software Simulation Method. Jurnal Teknik SIpil dan Perencanaan: UNNES Surabaya,21 (2), 122-123. doi 10.15294/jtsp.v21i2.20894

Brongtodiningrat, K. (1978). Arti Kraton Yogyakarta. Museum Kraton Yogyakarta.

Febrianto, R. S., Susanti, D. B., \& Istiqoma, M. (2018). Membaca Sistem Spasial Arsitektur Tradisional Dan Vernakular Dengan Strategi Penelitian Etnografi. Pawon: Jurnal Arsitektur, 2(02), 97-104. https://doi.org/10.36040/pawon.v2i02.258

Harapan, A. (2018). Sistem sambungan konstruksi rumah tradisional di kampung pulo, jawa barat. Jurnal Arsitektur Arcade, 2(2), 101-107.

Handayani (2019). Pengaruh Karakter Visual Bangunan Sekitar Terhadap Perancangan Fasad Bangunan Perpustakaan Nasional. Prosiding Seminar Intelektual Muda \#1, Inovasi IImu Pengetahuan, Teknologi Dan Seni Dalam Perencanaan dan Perancangan Lingkungan Terbangun.

Hasbi, R. M. (2017). Kajian Kearifan Lokal Pada Arsitektur Tradisional Rumoh Aceh. Vitruvian: Jurnal Arsitektur, Bangunan dan Lingkungan, 7(1), 2-3. https://publikasi. mercubuana.ac.id/index.php/virtuvian/ article/view/2717/1603

https://www.kratonjogja.id/tata-rakitingwewangunan/16/Pawon-ageng (diakses 21 Oktober 2020, pukul 21.00 WB).

Indonesian National Standard SNI 03-65722001. Procedures of Designing Ventilation System and Air Conditioning in Buildings. National Standardization Agency:Jakarta, Indonesia.

Nuryanto (2010). Fungsi dan Makna Pawon pada Arsitektur Sunda. Jurnal Teras UPI, 10(1), 45-46. http://jurnal.upi.edu/977/ view/255/fungsi-dan-makna-Pawon--padaarsitektur-sunda.html

Nuryanto (2020). Sosial-Ritual dan SimbolikMistik pada Pawon. Jurnal Arsitektur Zonesi, 3(2), 126-127. doi 10.17509/jaz. v3i2.24962

Prabasmara, P. G., Wibowo, S. H., \& Yuniastuti, T. (2020). Kajian Struktur Bangunan Tradisional Jawa pada Bangsal Kencana Keraton Yogyakarta. Sinektika: Jurnal Arsitektur, 16(1), 44-51. https://doi. org/10.23917/sinektika.v16i1.10491 
Punto, G. E. (2001). Kraton Yogyakarta dalam Balutan Hindu. Semarang: Bendera Semarang.

Rusnandar, N. (2015). Tatacara Dan Ritual Mendirikan Rumah. Jurnal PATANJALA, Kemdikbud, 7(3), 525-542. doi:http:// dx.doi.org/10.30959/patanjala.v7i3.117

Sabdacaraka, K. 2008. Sejarah Keraton Yogyakarta : NARASI.

Sary, R. K. (2015). Rumah Limas Palembang "Warisan Budaya Yang Hampir Punah. Jurnal Berkala Teknik UM Palembang, 5(2), 856-860. https://jurnal.um-palembang. ac.id/berkalateknik/article/view/365/33

Satriana,P.(2009). PerbandinganDapurTerbuka Tradisional dan Modern di Indonesia. Skripsi Arsitektur Universitas Indonesia, 1-1. http://lib.ui.ac.id/opac/themes/libri2/ detail.jsp?id=20249527\&lokasi=lokal

Sukirman (2011). Ragam Hias Bangsal Witana Sitihinggil Utara Keraton Yogyakarta, Kajian Iconologis. Tesis PascaSarjana Institut Seni Indonesia (ISI) Yogyakarta.

Widayatsari S. (2002), Tata Ruang Rumah Bangsawan Yogyakarta, Jurnal Dimensi Teknik Arsitektur, 30(2), 122-132. doi: https://doi.org/10.9744/dimensi.30.2.

Yuniastuti, T., Sukirman \& Satrio, H.B. (2009). Dokumentasi Bangunan Bangsal Tradisional Kraton Yogyakarta. Laporan Hasil Penelitian

Yuniastuti, T., \& Murti, D. A. K. (2019). Pengaruh Perubahan Fungsi Bangunan Pada Bentuk Bangunan Bangsal Banjar Andhap Dalem Mangkubumen Yogyakarta. Jurnal Arsitektur Pendapa, 2(1), 20-34. doi https://doi.org/10.20885/jars.vol4.iss 1.art3

Zain, Z. (2012). Analisis Bentuk dan Ruang pada Rumah Melayu Tradisional di Kota Sambas. NALARs, 11(1), 39-40. doi 10.24853/nalars.11.1.\%25p 